\title{
Use of Depleted Uranium Weapons in Contemporary Military Interventions
}

\author{
Ifesinachi Okafor-Yarwood
}

\begin{abstract}
This research note examines the use of depleted uranium weapons in contemporary military interventions and the hazardous effects of their use. It also demonstrates attempts made by the United States and the United Kingdom to block any international efforts to ban the use of these weapons. Although there is no laboratory evidence, experiential evidence from Iraq indicates that depleted uranium weapons are dangerous to human health and the environment. This research note argues that the United Nations should play a leading role in seeking a ban on the use of these weapons in military interventions.
\end{abstract}

Keywords depleted uranium weapons, military interventions, health and environmental implications, Iraq

\section{Introduction}

Although manufactured as early as the 1970s, depleted uranium (DU) weapons were first used by the American and British forces in the 1991 Gulf War, following the Iraqi invasion and occupation of Kuwait. DU weapons are made from uranium waste, and therefore contain chemically toxic and radioactive compounds (Hackman, Hackman, and Hackman 2002, 5-7). The post-war Iraqi government has attributed medical problems, particularly increases in cancers and genetic mutations in babies born after the war, to the use of DU munitions by the United States and the United Kingdom during the Gulf War (Hulme $2005,197)$. Whereas many observers, including academics and international organizations, continue to question the authenticity of such claims by the Iraqi government, others agree with the Iraqi position, especially those who had suspected the use of such weapons during the Balkan military campaigns in the 1990s (Norton-Taylor 2001).

It seems, therefore, that the extent of the damage done by $\mathrm{DU}$ weapons to the environment and human health is still a subject of debate. To date, there is no 
law prohibiting their use in military interventions. Some states have made their stance known on the dangers of the use of DU weapons and have called for a ban on their use. Others like the United States, the United Kingdom, China, Israel, and Japan, who are producers and/or users of such weapons, have continued to support their use (Hulme 2005, 269). Yet, they have failed to spearhead cleanup exercises in areas where DU munitions were deployed in line with the World Health Organization (WHO)'s guidelines, which exhort that, "where possible cleanup operations in conflict impact zones should be undertaken" (WHO 2001, vi).

In light of this conflicting and complex picture, this research note aims to tackle the following controversial issues: reasons for the manufacture and use of DU weapons, and their effects on human health and the environment. Also, this note reviews the legal framework surrounding the use of DU weapons, and then briefly discusses actual use of DU weapons, particularly in the Balkan region.

\section{Why DU?}

The natural isotopes of uranium occur in three different forms: U234, U235, and U238. Fissionable U235 accounts for only $0.72 \%$, whilst more than $99 \%$ consists of unfissionable U238. When the U235 isotope is separated out the waste product generated is known as "depleted uranium." Despite its hazardous and radioactive nature, a DU weapon is not itself a nuclear weapon as it is incapable of an atomic chain reaction and contains only a minute residual amount of fissionable U235 (Hulme 2005, 206). Thus, DU is a by-product of the enrichment process used to generate fuel for nuclear power or for the production of nuclear weapons. For the purpose of this research note, DU weapons will be defined as point weapons that are made from nuclear by-products and are designed to impact a specific, distinct target (Hulme 2004, 12).

According to one source, more than 50,000 metric tons of DU are added to the already extensive existing stockpiles in the United States, Europe, and Russia every year. The total quantity of DU accumulated by both producers and users of nuclear energy and weapons across the world now amounts to over 1.2 million metric tons (Riley 2004, 36).

The United States is the major producer of DU weapons. Having completed and tested their first nuclear weapon in 1945, U.S. scientists were faced with the problem of the accumulation of nuclear by-products. Rather than view DU as unused waste that would require costly and possibly dangerous disposal, they sought to find uses for DU and, accordingly, championed research on ways of accomplishing their aims. They discovered that DU had exceptional properties that were very appealing. Most notably they found that, in comparison to other metals such as tungsten and lead, DU had much higher density. Hence they 
proposed to use it in the production of weapons. The first such weapons were successfully manufactured in the 1970s and were first used in the 1991 Gulf War (Nobuo 2010, 236; Hulme 2005, 197).

Why is DU preferred over other metals? First, since uranium is about 2.5 times heavier than iron and 1.7 times denser than lead, DU munitions have the capability of penetrating more deeply and traveling farther than conventional munitions. DU is also known to be pyrophoric, which means that it ignites spontaneously on contact with the air. As a result of these physical and chemical properties, DU is used in the manufacture of weapons intended to penetrate armor plate and correspondingly to reinforce military vehicles and tanks (Tyner 2010, 147). When DU munitions strike a vehicle, for example, they do not explode as conventional weapons do; rather, they penetrate into the vehicle, cremating all the occupants. DU kinetic energy penetrators are the best-known advanced munitions, partly because of the publicity they received after their use in the First Gulf War by the coalition forces (McClain and Miller 2007, 2).

One of the reasons why the U.S. Department of Defense (DoD) switched to the use of DU weapons was the U.S. Navy's indication that DU was the best material available for munitions (Fahey 2008a, 7). This reasoning is based on experience during the Gulf and Iraq wars in which DU rounds were said to have been instrumental in the U.S. and British military defeat of the Iraqi military, as the former's weapons were more sophisticated and revolutionary compared to the latter's outdated Soviet tanks (Nobuo 2010, 237). This informed the use of DU weapons by the United States during their military intervention in the Balkan States between 1994 and 1995, the Iraqi war in 2003, and the Afghan war against the Taliban. ${ }^{1}$

Second, DU is a waste product derived from an already existing nuclear industry. This makes it accessible and sometimes available to manufacturers at little or no cost in the manufacture of armored plating or munitions. The cost of artillery shells and other ammunitions produced with DU is about $10 \%$ of the cost of those weapons manufactured with other metals like tungsten. Furthermore, at least $50 \%$ of the U.S. tungsten requirement is imported from China at a very high cost, while DU costs the weapons manufacturers almost nothing (Tyner 2010, 149).

The following are some additional reasons for the use of DU weapons. Use of DU addresses the problem of increasing quantities of toxic waste from the production of nuclear weapons and from nuclear power plants. Furthermore, defense companies are able to source materials locally and free of charge, thereby reducing the defense budgets in a time of military budget cuts while avoiding strategically undesirable dependency on the importation of tungsten. Finally, and most importantly, militaries are able to add "superb and innovative" weapons to their arsenals (Tyner 2010, 149). Bearing in mind the evidence set forth above, one might be right to conclude that the use of DU in the production of weapons 
Figure 1. Various Kinds of DU Rounds from $30 \mathrm{~mm}$ to $120 \mathrm{~mm}$

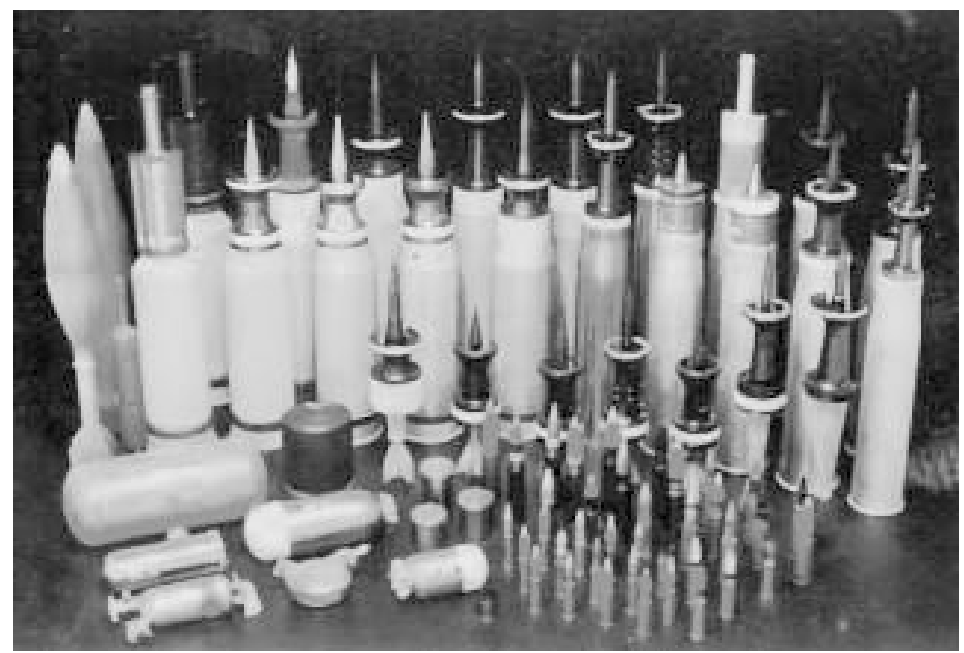

Source: Duff 2011.

presents an overall success for all parties who are involved in the manufacture of nuclear weapons, the generation of nuclear power, or in military operations.

However, in using the phrase "overall success for all parties" the meaning is restricted to weaponry. A wider judgment is needed on whether the expediency of winning wars comes at a far-reaching and, arguably, unacceptable price in terms of lingering and accumulative damage to non-combatant human life and the environment.

\section{Health and Environmental Implications of the Use of DU}

The impact of DU weapons on human health and the natural environment has been the subject of extraordinary claims by both parties, those favoring and those opposing their use. It has proven difficult to separate fact from fiction, and it is now clear that not enough is known about the effects of DU weapons to be able to reach a definite conclusion either way. It is perhaps not surprising that this subject offers fertile ground for disagreement since the United States and the United Kingdom appear to be opposed to further investigation of the health and environmental implications of the use of DU weapons (White 2008, 39-47). Such political convenience of governments is served by the medical and scientific fact that any damaging side effects are slow to materialize and hence, as yet, there is little substantial evidence to compel such investigation.

Nevertheless, the following observations can be made about some of the potential health and environmental implications of the use of DU Weapons: 
First, the use of DU in weapons carries the risk of radiation exposure to both combatants and non-combatants. Upon impact a DU penetrator quickly oxidizes, dispersing toxic uranium oxide dust particles. If, for example, a person were to ingest or inhale such particles, these could enter the bloodstream and circulate throughout the body, thus exposing the victim to internal radiation.

It is a well-known fact that only about 10 electron volts of energy are needed to damage DNA or other body molecules. Since DU is a very powerful emitter of alpha particles (up to 4.2 million electron volts per particle), one can easily envisage the severe effects of such exposure on military combatants, noncombatants, and the general public (Ammash 2003, 205, 207). In addition, it is also believed that prolonged exposure to internal radiation can cause severe health problems, including cancer (especially leukemia, lung, and bone cancer), pulmonary and lymph node fibrosis, pneumoconiosis, inhibition of reproductive activities, and other life threatening health problems (Ammash 2003, 205-206).

According to a report by the WHO on the effects of DU on human health and the environment following its use by the North Atlantic Treaty Organization (NATO) against the former Federal Republic of Yugoslavia, there is a possibility that DU possesses chemical and radiological toxicity which can target two of the most important organs of the body: the kidneys and the lungs. However, the WHO stressed that the health implications for a specific individual can only be determined by the physical and chemical nature, level, and duration of DU exposure which a person has experienced. The report went on to state that only military use of DU is likely to have substantial impact on an environmental scale, but acknowledged that further research is needed to establish the level of health and environmental impacts of DU weapons (WHO 2001). Ironically, the WHO has been accused of covering up the true impact of DU weapons, as they refuse to share evidence that the U.S. use of DU weapons in Iraq contributed to an increased number of birth defects in that country (Edwards 2004; Cromwell 2013).

Another report from the British Royal Society (BRS) found that there exist radiological risks from the use of DU in weapons, but that these risks are very minute. At the same time they determined that for the small numbers of soldiers who were exposed to DU weapons there might be circumstances in which risks could be higher. Like the WHO, the BRS also asserted that for a conclusive determination to be made on the real health impact of DU weapons more research must be undertaken (McDonald 2001, 323-324).

Second, DU is not only thought to be damaging to human and animal health, but also to the environment, as some of the highly toxic heavy metal released by DU is roughly $60 \%$ as radioactive as naturally occurring uranium, and is said to have a half-life of 4.5 billion years. The implication is that these radioactive particles decay extremely slowly and, in effect, can cause permanent damage to the environment (Nobuo 2010, 237; Bleise, Danesi, and Burkart 2003, 
102-104).

In addition, for every 100 DU weapons fired in war only 10 find their intended targets, with the remaining 90 penetrating deeply into the earth, entering the soil and the water table as they decay. This is certainly dangerous for the ecosystem as it becomes impregnated with heavy metals, which are consequently a threat to human and other life forms through the food chain (Parrish et al. 2008, 68).

The United Nations Environmental Program (UNEP), in recognition of the effects DU weapons can have on the environment, has stated that heavy firing of DU in a concentrated area could increase the potential level of uranium contamination of the ground water by a factor of 10 to 100, thus heavily contaminating water resources (UNEP 2001). As a result of such danger existing in the soil and water table, the WHO has recommended that, where possible, cleanup operations should be undertaken in areas where such weapons have been used, and in some cases affected areas should be off limits to use by the public until the cleanup exercise has taken place (WHO 2001). Despite these findings, countries such as the United States and international organizations like NATO have continued to use DU weapons in their military and/or humanitarian intervention campaigns, without cleanup. Thus, unless the use of DU weapons is banned, there is the danger of continuous increase in the number of hibakushas in the world ${ }^{2}$ and endless pollution of our ecosystems (Nobuo 2010, 240).

There follows in the next section a more detailed review of the struggle for transparency as to the legal implications of the use of DU munitions in military conflicts.

\section{Military Transparency}

James Tyner's 2010 text Military Legacy: A World Made by War was further testament to the fact that certain wars, especially ones that involve the use of nuclear weapons or DU munitions, are detrimental not only to the victims but also to the victors, as they both suffer the effects of exposure to radiation. He argued that, although DU weapons were instrumental to the success of the coalition forces in the Gulf War (and also to the subsequent ending of the conflict in the Balkans), the victory was marred because within two years of the end of the Gulf War veterans, both in the United States and the United Kingdom, began to complain of "mysterious" illnesses with symptoms such as weakness, fatigue, and respiratory and kidney problems.

Moreover, children born to veterans of the war were found to exhibit higher rates of birth defects and other genetic deformities, and doctors also documented increased incidence of cancers and leukemia in such children. These symptoms and effects were later termed the "Gulf War Syndrome" (2010, 150). It is 
noteworthy that the apparent damaging effects of DU munitions are not limited to soldiers that have had direct contact with them, but such weapons can also have adverse consequences for civilian populations. For example, studies in Iraq have shown various forms of cancer in $40-48 \%$ of the population in some areas, and this abnormally high level has been attributed to the use of DU munitions by the coalition forces (Deely 2005, 124).

However, since there is no single international agreement forbidding the use of DU weapons, and because of the alleged lack of conclusive evidence as to the effects of DU weapons on veterans, civilians, and the environment, states have continued to produce and use these weapons. For example, the U.S. government has defended the safety of its use of DU weapons based on their own experiments. However, subsequent reports from scientists and experts in the field have shown that those studies are inadequate and biased. In 2003, the Nuclear Policy Research Institute (NPRI) in Washington, D.C. produced a report suggesting that the U.S. government was selective in its conclusions about the real impact of DU weapons. The NPRI presented the following evidence:

First, a 1993 study done by the U.S. General Accounting Office following the outbreak of the "Gulf War Syndrome" concluded that "inhaled insoluble oxides stay in the lungs longer and pose a potential cancer risk due to radiation." Second, in 1995 another study by the Army Environmental Policy Institute further documented the negative health effects of DU weapons, stating that "if DU enters the body, it has the potential to generate significant medical consequences; and that the risks associated with DU in the body are both chemical and radiological." In addition, the report expressed the view that, notwithstanding such research and findings by these government agencies, the U.S. government in their final report, entitled "Presidential Advisory Committee on Gulf War Veterans' Illnesses," made public in 1996, had made a statement of questionable validity. That statement concluded that "it is unlikely that health effects reported by Gulf War veterans today are the result of exposure to DU during the Gulf War" (Presidential Advisory Committee on Gulf War Veterans' Illnesses 1996, 120).

If DU weapons have no negative effects on human health and the environment-as the reports from producing and using countries suggest-then why has the U.S. government made it difficult for further studies to be carried out by international agencies to examine the extent of any damage done by the use of DU weapons during the Gulf War? Evidence for U.S. resistance to such studies is manifested in U.S. lobbying of the UN General Assembly, in November 2001, to reject a longstanding proposal from the Iraqi government requesting a detailed study on the effects of the use of DU in the Gulf War, notwithstanding that this proposal had already been approved by the UN Committee on Disarmament and International Security (Nuclear Policy Research Institute 2003, 14).

Furthermore, in 1995, an article carried by the U.S. Army magazine Armour contradicted some of the reassuring reports by the government on the effects 
of DU on the environment. The article offered advice to military officers living or working in DU contaminated environments. For instance, they are to "take care to ensure food, shower and bivouac sites are not in an area of known DU contamination or where DU dust may have been carried by recent rains..." (Paulsen 1995, 34). Surely this advice for soldiers should also apply to civilians, and shows there is need for urgent study and prompt decontamination of areas where DU weapons have been deployed.

Likewise, if, as suggested by the producers and users of DU weapons, their use has no negative effects on the veterans and the civilian populations exposed to them, then there should be alternative explanations, other than the exposure to radiation in military conflict, for the deaths of soldiers from different forms of cancer after serving in the coalition forces during the Balkan conflict. In fact, the linkage between such weapons and disease was recognized when an Italian court awarded $€ 500,000$ in compensation to the widow of Stefano Melone, a soldier who had served as a helicopter pilot in Kosovo, and who had died in 2001 from malignant pleuro-pulmonary neoplasia (epithelioid hemangioendothelioma of the bone, the lung, and the pleura), a very rare form of cancer which doctors attributed to radiation exposure (Albanian Economy News 2008).

Similarly, if the use of DU weapons were of no threat to the environment, then there would have been no need for the British government to offer, in April 2003 , to help with the clean-up of such munitions that were used by the coalition forces in Iraq (Kirby 2003).

\section{Legal Perspectives}

Regrettably, no treaty has so far been enacted that makes it specifically illegal for DU munitions to be used in armed conflict; neither is there any treaty limiting their use in military intervention. Due to their characteristics, there may be legal grounds for prohibiting the use of DU weapons, or at least for having their use limited under existing laws overseeing other weaponry. DU is both radiologically and chemically toxic; therefore, the closest analogous weapons in terms of their health and environmental effects would be nuclear or chemical weapons. According to the UN General Assembly in its 1961 Declaration on the Prohibition of the Use of Nuclear and Thermo-Nuclear Weapons: "[A]ny State using nuclear or thermo-nuclear weapons is to be considered as violating the Charter of the UN, as acting contrary to the laws of humanity and as committing a crime against mankind and civilization" (Hulme 2005, 233-234). ${ }^{3}$

Furthermore, the 1963 Treaty on Banning Nuclear Weapons Tests in the Atmosphere, in Outer Space and Under Water, signed by the United States and the United Kingdom among others, expressed states' desire to "put an end to the contamination of man's environment by radioactive substances" (Hulme 2005, 
238). This mandate was repeated in the nuclear free zone treaties for the South Pacific, African, and Southeast Asian regions, which declared that the regions should be kept "free of environmental pollution by radioactive wastes and other radioactive matter."

The use of DU munitions by state parties appears to be in clear violation of the objectives of these treaties and declaration. But as Hulme notes, because they refer only to the use of nuclear weapons and contain no specific mention of DU weapons (which, as we have seen above, are radioactive but not nuclear), there seems to be an inadequate legal framework within which to hold both the producers and users of such weapons accountable for their alleged violations of humanity and the planet.

Similarly, DU weapons are comparable to chemical weapons as both types of weapons have chemically toxic effects. It is important to note that chemical weapons have a longer battle history than nuclear weapons and, as a result of their devastating effects, their use is "completely banned" under the 1993 Chemical Weapons Convention, which prohibits the development, production, stockpiling, and use of chemical weapons, and governs procedures for their destruction. However, based on what constitutes a toxic material under the Convention, regrettably, DU is not classified as a toxic chemical and as a result does not fall within the criteria for prohibition (Hulme 2005, 238, 241, 243). It will be seen, therefore, that there is no international treaty prohibiting the use of DU munitions despite the reports setting forth evidence of the damaging effects of their use in the Gulf region and elsewhere.

These weapons were deployed by the coalition forces under NATO's authority in Bosnia, Serbia, and Kosovo between 1994 and 1999, and subsequently in the military campaign by both the U.S. and the UK governments in Iraq in 2003. More recently, according to the International Coalition to Ban Uranium Weapons (ICBUW), leaked transport documents suggest that DU weapons have also been deployed by U.S. forces in Afghanistan (ICBUW 2007). There is also increasing

Figure 2. Countries with DU Weapons Deployment

\begin{tabular}{c|c|c|c|c|c}
\hline \hline & $\begin{array}{c}\text { The } \\
\text { Gulf War: } \\
1991\end{array}$ & $\begin{array}{c}\text { Bosnia: } \\
1994-1995\end{array}$ & $\begin{array}{c}\text { Kosovo, Serbia, } \\
\text { Montenegro: } \\
1999\end{array}$ & $\begin{array}{c}\text { Afghanistan: } \\
2001-2003\end{array}$ & $\begin{array}{c}\text { Iraq: } \\
2003\end{array}$ \\
\hline $\begin{array}{l}\text { Weapons } \\
\text { Systems }\end{array}$ & $\begin{array}{c}\text { U.S. aircraft } \\
\text { and tanks; } \\
\text { UK tanks }\end{array}$ & $\begin{array}{c}\text { U.S. } \\
\text { aircraft }\end{array}$ & $\begin{array}{c}\text { U.S. } \\
\text { aircraft }\end{array}$ & U.S. aircraft & $\begin{array}{c}\text { U.S. aircraft, tanks } \\
\text { and fighting } \\
\text { vehicles; } \\
\text { UK tanks }\end{array}$ \\
\hline Quantity & $\begin{array}{c}286 \\
\text { metric } \\
\text { tons }\end{array}$ & $\begin{array}{c}3.2 \\
\text { metric } \\
\text { tons }\end{array}$ & $\begin{array}{c}9.5 \\
\text { metric } \\
\text { tons }\end{array}$ & Uncertain & Uncertain \\
\hline
\end{tabular}

Source: Bernard et al. 2005. 
speculation that DU weapons were utilized by both the U.S. and NATO forces during the 2011 NATO intervention in Libya (Gelling 2011).

\section{Use of DU Weapons in the Balkans}

In order to understand more clearly the possible implications of the use of DU weapons, a closer examination of their use in the Balkans by NATO and its coalition forces between 1994 and 1999 is valuable. It is worth noting that by the time of the Kosovo conflict in 1999, there already existed significant international interest in both the use and after-effects of DU munitions. As we have seen, this interest was mainly a result of claims made about the military effectiveness of their deployment in the Gulf War of 1991, and illnesses subsequently suffered by some of the veterans who took part in that war. Concern about the health effects was overwhelming, so much so that two months after the end of the military campaign in Kosovo, and long before the exact quantities and locations of DU weapons had been identified by scientists from international organizations, Roger Coghill, a British scientist, claimed that "America's use of DU weapons in the war with Serbia is likely to cause 10,000 extra deaths from cancer" (Kirby 1999).

Moreover, according to UNEP, following its sampling of sites in Bosnia and Herzegovina in 2002, "If there is widespread measurable contamination of the ground surface by DU, there is a risk that some DU will become airborne through wind action and subsequently be inhaled by people. There is also a possibility of contamination of food (fruit, vegetables, meat, etc.) and drinking water" (UNEP 2003 , 19). In line with this risk of exposure by inhalation, Hulme, in her book, War Torn Environment: Interpreting the Legal Threshold, explains further that the dust created when DU munitions are fired usually consists of both soluble and insoluble particles, and the soluble uranium substance if inhaled as either fume or gas is absorbed into the bloodstream. Although most of these impurities will be excreted from the body relatively quickly, there are still risks that severe damage can be caused to the kidneys given their function as the body's filter, and so it is in these organs that most chemical components of the inhaled dust would accumulate (Hulme 2004, 229). She went on to state that, contrary to the reports by some agencies on the lasting extent of the damage of soluble uranium to the kidneys, other government scientists have stated that such kidney damage is likely to be reversible.

The insoluble uranium particles created on the impact of DU weapons, on the other hand, do not dissolve in the bloodstream and circulate in the body and hence exhibit low chemical toxicity to the body as a whole. However, by their nature the particles are likely to settle in the first organ contacted: the lungs, if inhaled; the stomach, if ingested; or under the skin, if embedded in a wound. Such insoluble dust can cause localized radiation damage to the organs in which 
it lodges as a result of the presence of alpha particles. For example, if insoluble uranium material is inhaled and retained in the body for too long, it can cause damage to lung tissue (Hulme 2004, 229-230). It is important to note that other government and international sources, including NATO, have consistently stated that the effects of DU on human health and the environment set forth in scientific findings such as the ones cited by Hulme are "negligible" (NATO 2001).

Regarding the effects of the use of DU weapons on the environment, tests carried out by UNEP $(2003,32)$ in Bosnia and Herzegovina found localized ground contamination around the site of impact with widely variable concentrations: $0.01-100 \mathrm{~g} \mathrm{DU} / \mathrm{kg}$ of soil. One of their most important findings was related to the dispersion of soil contamination over time. In the five years since impact, the detectable dispersion depth had reached 10 to $40 \mathrm{~cm}$, compared to the Kosovo findings of a depth of only 0 to $10 \mathrm{~cm}$.

Results such as those set forth above have caused bodies such as the WHO to remain concerned about the continued use of DU munitions, and the European Parliament has gone a step further by calling for a halt to the use of any form of DU weapons until their effects have been conclusively assessed (ICBUW 2008).

\section{Conclusion}

The principal findings of this research note may be summarized as follows: DU weapons were first used by the American and British forces in the 1991 Gulf War and have been used subsequently in several theaters of action. They are cheap to produce and highly effective militarily. They are made from uranium waste, and therefore they contain chemically toxic and radioactive compounds. There is a widespread concern as to the lasting damage that may be caused by the use of DU weapons to human life and the environment. Therefore, this note suggests that there are a number of inter-related factors that need to be considered.

The military, strategic, and cost-effective benefits of DU weapons are undeniable and present compelling reasons for the U.S. and UK governments and NATO to continue to favor their use and to play down any lasting and damaging effects. Similarly, control of the use of such weapons is difficult because, although some research has been done, it is so far considered insufficient (given the delayed effects on health and the environment). It is probably too early to provide definitive scientific proof as to the damage caused by DU weapons on combatants, non-combatants, and the environment, despite the availability of some harrowing case reports.

In addition, DU weapons, although both radioactive and toxic, are not nuclear. They therefore do not fall within the UN's definition of chemical weapons and, as such, there exists no clear legal framework banning their use. Based on the evidence presented and the arguments for and against the health and 
environmental implications of the use of DU weapons, it is clear that the signing of a treaty banning the use of DU weapons would currently be very difficult to achieve.

Given this impasse, what does the future hold? The response to this question lies in understanding, first, that it is probable that the U.S. and British governments will continue to claim that DU is relatively harmless-a position which is, at best, the result of only a small number of studies together with inaccurate interpretation of such limited information available to them and, at worst, a continuing culture of non-disclosure.

Second, unless and until such evidence becomes available, it will be difficult to implement any form of ban on the production, possession, trade, and use of DU weapons. Dekker added that one of the possible reasons why the use of DU weapons may be difficult to ban is "due to the near impossibility of supervision of compliance" $(2008,92)$.

Third, while working toward a ban on these weapons, there is a need for a set of transparency measures regarding DU munitions to be established amongst producers and users, bearing in mind that this measure should not in any way serve as a substitute for a treaty prohibiting their use (Fahey 2008b, 72; Dekker 2008 , 97). Most importantly, as recommended by the WHO, cleanup exercises should be carried out, particularly in heavily contaminated areas, to reduce the possible effects of DU exposure.

Finally, as evidence accumulates it seems appropriate to look ahead with optimism to a time when the use of DU in warfare will be either prohibited or limited, based on the principles of Article 35 (2) of the Geneva Protocol I, which states that "it is prohibited to employ weapons, projectiles and materials and methods of warfare of a nature to cause superfluous injury or unnecessary suffering" (Hulme 2005, 245-246).

\section{Notes}

1. The use of DU weapons in Afghanistan has not been confirmed; however, evidence of the transportation of such weapons in the region has been uncovered (ICBUW 2007).

2. The term of hibakusha was first used to describe the survivors of A-bomb radiation in Hiroshima and Nagasaki, but is now used generally to describe any victims of atomic radiation.

3. It is noteworthy that unlike treaties, declarations are not legally binding in international law; as such it is impossible to hold states accountable for not adhering to it (Dixon et al. 2011, 51-52). 


\section{References}

Albanian Economy News. 2008. "Italy to Compensate Soldiers for NATO Depleted Uranium Cancer." December 18. http://archives.econ.utah.edu/archives/a-list/2008w50/ msg00103.html (accessed March 19, 2014).

Ammash, Huda S. 2003. "Toxic Pollution, the Gulf War, and Sanctions: the Impact on the Environment and Health in Iraq." In Iraq under Siege: The Deadly Impact of Sanctions and War, ed. Anthony Arnove. United Kingdom: Pluto Press, 205-216.

Bernard, Kimberly, Martin Butcher, Roy Farrell, Robert M. Gould, and Michael McCally. 2005. "DU: Health and Public Health Issues Arising from the Use of Depleted Uranium Munitions.” Physicians for Social Responsibility. http://action.psr.org/ documents/du_report.pdf (accessed December 10, 2013).

Bleise, Andreas, Danesi, Pier Roberto, and Burkart Werner. 2003. "Properties, Use and Health Effects of Depleted Uranium (DU): A General Overview." Journal of Environmental Radioactivity 64: 93-112.

Cromwell, David. 2013. "Damning Evidence Becomes No Clear Evidence: Much Delayed Report on Congenital Birth Defects in Iraq." Media Lens, September 19. http://www. medialens.org/index.php?option=com_content\&view $=$ article\&id=741:damningevidence-becomes-no-clear-evidence-much-delayed-report-on-congenital-birthdefects-in-iraq\&catid=51:alerts-2013\&Itemid=202 (accessed January 30, 2014).

Deely, Sean. 2005. "War, Health and Recovery." In After the Conflict: Reconstruction and Development in the Aftermath of War, ed. Sultan Barakat. London: I.B. Tauris Publications, 123-140.

Dekker, Guido Den. 2008. “The Law of Arms Control and Depleted Uranium Weapons.” In Depleted Uranium Weapons and International Law: A Precautionary Approach, eds. Avril McDonald, Jann K. Kleffner, and Toebes Brigit. United Kingdom: T.M.C. Asser Press, 75-98.

Duff, Gordon. 2011. "Nuclear Terrorism: Secret Science and America's Cowboy Nukes." Veterans Today, November 7. http://www.veteranstoday.com/2011/11/07/nuclearterrorism-secret-science-and-americas-cowboy-nukes/ (accessed February 20, 2014).

Edwards, Rob. 2004. "WHO Suppressed Scientific Study into Depleted Uranium Cancer Fear in Iraq." The Sunday Herald, February 22. http://www.freewebs.com/ killerpillresearch/who\%20suppressed\%20print.pdf (accessed December 11, 2013).

Fahey, Dan. 2008a. "Depleted Uranium and Its Use in Weapons." In Depleted Uranium Weapons and International Law: A Precautionary Approach, eds. Avril McDonald, Jann K. Kleffner, and Toebes Brigit. United Kingdom: T.M.C. Asser Press, 3-28.

Fahey, Dan. 2008b. "Environmental and Health Consequences of the Use of Depleted Uranium Weapons." In Depleted Uranium Weapons and International Law: A Precautionary Approach, eds. Avril McDonald, Jann K. Kleffner, and Toebes Brigit. United Kingdom: T.M.C. Asser Press, 29-74.

Gelling, Peter. 2011. "Is NATO Using Dirty Bombs in Libya?" Global Post, July 7. http:// www.globalpost.com/dispatches/globalpost-blogs/the-casbah/nato-libya-dirtybombs-depleted-uranium (accessed January 29, 2014).

Hackman, Christian L., E. Ellsworth Hackman, and Mathew E. Hackman. 2002. Hazardous Waste Operations and Emergency Response Manual and Desk Reference, 
Volume 1. New York: McGraw-Hill Professional Engineering Publications.

Hulme, Karen. 2004. War Torn Environment: Interpreting the Legal Threshold. Netherlands: Martinus Nijhoff Publishers.

Hulme, Karen. 2005. "Radiation Warfare: A Review of the Legality of Depleted Uranium Weaponry." Canadian Yearbook of International Law 43: 197-295.

ICBUW. 2007 "Leaked US Army Transport Letter Suggests DU in Afghanistan." January 29. http://www.bandepleteduranium.org/en/a/113.html (accessed February 20, 2014).

ICBUW. 2008. "European Parliament Passes Far Reaching DU Resolution in Landslide Vote.” May 22. http://www.bandepleteduranium.org/en/a/181.html (accessed November 20, 2013).

Kirby, Alex. 1999. "Depleted Uranium Threatens Balkan Cancer Epidemic." BBC News, July 30. http://news.bbc.co.uk/1/hi/sci/tech/408122.stm (accessed January 29, 2014).

Kirby, Alex. 2003. "UK to Aid Iraq DU Removal." BBC News, April 23. http://news.bbc. co.uk/1/hi/sci/tech/2970503.stm (accessed November 20, 2014).

Martin, Dixon, Robert McCorquodale, and Sarah Williams. 2011. Cases and Materials on International Law. Oxford: Oxford University Press.

McClain, David E., and Alexandra C. Miller. 2007. "Depleted Uranium Biological Effects: Introduction and Early in Vitro and in Vivo Studies." In Depleted Uranium: Properties, Uses, and Health Consequences, ed. Alexandra C. Miller. Boca Raton, FL: CRC Press, $1-20$.

McDonald, Avril. 2001. "The Year in Review." Yearbook of International Humanitarian Law 4: 255-327.

NATO. 2001. "Statement by the Secretary General on the Use of Depleted Uranium Munitions in the Balkans." January 10. http://www.nato.int/docu/pr/2001/p01-002e. htm (accessed November 19, 2013).

Nobuo, K. 2010. "Depleted Uranium Weapons as the Nuclear Shadow: Iraq War as Seen from Hiroshima." In Hiroshima \& Peace, eds. Carol Rinnert, Omar Farouk, and Inoue Yasuhiro. Hiroshima: Keisuisha Co. Ltd, 230-244.

Norton-Taylor, Richard. 2001. "Italy Alarmed by Balkan Syndrome." The Guardian, January 4. http://www.guardian.co.uk/world/2001/jan/04/balkans?INTCMP=SRCH (accessed January 30, 2014).

Nuclear Policy Research Institute. 2003. "Depleted Uranium: Scientific Basis for Assessing Risk." http://www.helencaldicott.com/depleted.pdf (accessed January 30, 2014).

Parrish, Randall R., Matthew Horstwood, John G. Arnason, Simon Chenery, Tim Brewer, Nicholas S. Lloyd, and David O. Carpenter. 2008. "Depleted Uranium Contamination by Inhalation Exposure and Its Detection after 20 Years: Implications for Human Health Assessment." Science of the Total Environment 390 (1): 58-68.

Paulsen, Pat. 1995. "Depleted Uranium without the Rocket Science." In Crisis in Battle: The Conduct of Assault, ed. A. Blakely Terry. Fort Knox, KY: Armour Publications, 33-34.

Presidential Advisory Committee on Gulf War Veterans' Illnesses. 1996. "Final Report." Washington, D.C.: United States Government Printing Office.

Riley, Peter. 2004. Nuclear Waste: Law, Policy and Pragmatism. Hants, England: Ashgate Publishing.

Tyner, James A. 2010. Military Legacies: A World Made by War. New York: Routledge.

UNEP. 2001. "United Nations Environment Programme Recommends Precautionary Action Regarding Depleted Uranium in Kosovo.” March 14. http://www.unep.org/ 
Documents. Multilingual/Default.asp?DocumentID=193\&ArticleID=2789 (accessed January 30, 2014).

UNEP. 2003. "Depleted Uranium in Bosnia and Herzegovina: Post-Conflict Environmental Assessment, A Report by the United Nations Environment Programme." Imprimerie Chirat, France: UNEP.

White, Rob. 2008. "Depleted Uranium, State Crime and the Politics of Knowing." Theoretical Criminology 12 (1): 31-54.

WHO. 2001. "Depleted Uranium: Sources, Exposure and Health Effects." Geneva: Department of Protection of the Human Environment, WHO. http://www.who.int/ ionizing_radiation/pub_meet/en/Depluraniumintro.pdf (accessed January 30, 2014).

Ifesinachi Okafor-Yarwood is a Master of Arts Associate of the African Leadership Centre, Kings College London, and was a visiting scholar at the University of Nairobi from October 2013 to February 2014. Her most recent degree is an M.A. in Conflict, Security and Development from King's College London. Okafor-Yarwood also has a B.A. in International Relations and Peace and Conflict Studies, from London Metropolitan University. E-mail: ifeokafor@googlemail.com 
